\title{
非構造移動格子有限体積法*
}

（第 3 報，非定常問題に対する格子細分化非構造解適合格子形成法）

$$
\text { 山川勝 史*1, 松 野謙—*1 }
$$

\section{An Iterative Finite-Volume Method on an Unstructured Moving Grid (3rd Report, Unstructured Adaptive Mesh Refinement Method for Unsteady Problems)}

\author{
Masashi YAMAKAWA*2 and Kenichi MATSUNO \\ ${ }^{* 2}$ Department of Mechanical and System Engineering, Kyoto Institute of Technology, \\ Gosyokaido cho, Matsugasaki, Sakyo-ku, Kyoto-shi, Kyoto, 606-8585 Japan
}

\begin{abstract}
A new adaptive mesh refinement method for unsteady compressible flow is presented in this paper. For unsteady flow problem, the solution-adapted grid is also dynamically changing its shape at every time step according to the flow change since the flow is non-stationary. For the present solution-adapted grid method, two grid cells are merged into one grid cell and one grid cell is divided into two grid cells according to a criterion of grid adaption in a time-dependent way in unstructured grid system. In this case, it is important to assure geometric conservation low as well as physical conservation low on such the grid system. Therefore, we adopt a finite volume method in which a control volume on the space-time unified domain for estimating numerical flux. The method is described and applied for two-dimensional unsteady compressible flows.
\end{abstract}

Key Words : Computational Fluid Dynamics, Compressible Flow, Unsteady Flow, Unstructured Mesh, Solution-Adapted Grid Method

\section{1.}

近年，計算機が著しい発達を遂げたとはいえ，よ り詳細な流れ場を計算するには莫大な時間と計算機容 量が必要となる. この問題に対する有効な手法の一つ として解適合格子形成法がある. 解適合格子形成法は 流れ場の重要な部分（例えば圧縮性流体における衝撃 波部）の計算格子を密に，それ以外を柾に配置するこ とにより計算効率向上を狙ったものである. 特に定常 問題に対しては, 格子線を移動させる方法(1), 格子を 局所的に細分化する方法®，また重畳格子法と組合せ ることでより効率を高める方法(等様々な方法が提案 されており，ほぼ実用の域に達していると言えよう.

一方，非定常問題に対し解適合格子を形成する場 合には幾つか注意すべき項目があり，その一つに幾何 保存則が挙げられる. 通常, 非定常問題では時間と共 に解が変化し，その解の変化に合わせて解適合格子も 時々刻々と変化することになる. この場合，幾何保存 則(のが満足されていなければ，時間と共に変化する

\footnotetext{
* 原稿受付 2005 年 3 月 14 日.

*1 正員, 京都工芸織維大学工芸学部( $\mathbf{E} 606$-8585 京都市左京 区松ヶ崎御所海道町).

E-mail : yamakawa@kit.ac.jp
}

格子が流れ場に影響を与え, 結果的に計算誤差が蓄積, または計算不能に陥る可能性が高くなる.この幾何保 存則の崩壊を回避する手段として, 著者らは時間一空 間を合わせたコントロールボリュームを形成し，その 時間と共に変化する検査体積について幾何保存則を満 たすように離散化した非構造移動格子有限体積法的を 提案している. つまり本手法に解適合機能を付加させ ることで, 非定常問題に対し幾何保存則を満足させた 解適合格子形成を行うことが可能になると考えられる. 非定常問題に対し解適合格子を行う手法(ぬは多々あ るが, 本論文のように幾何保存則についてまで言及し たものは確認していない.

さて，非構造格子を用いて解適合格子を形成する 場合, 格子細分化法は効率良く格子点を配置できるこ とから非常によく用いられている. 格子を密にする筒 所では格子点を追加（要素を分割）し，格子を疎にす る箅所では格子点を消减（要素を結合）させるもので ある. ただしこの格子細分化法を非定常問題で行うた めには，時間と共に格子点を追加および消滅させても 物理およひ幾何保存則を同時に満足させる必要が生じ るが，これに対しては著者らが前報けにて定式化した 手法を応用することとする. 
本論文では二次元非粘性圧縮性流れを対象に，ま ず格子点の追加・消减を伴う非構造移動格子有限体積 法の定式化を簡単に示し, 検証問題, 実用問題を通し て本手法の有効性を示す.

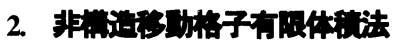

非定常問題に対し格子細分化法を用いた解適合格 子を形成する場合, 時間と共に格子点を追加・消减 させることとなる. この時, 常に幾何保存則を満た すよう離散化された非構造移動格子有限体積法は以 下のようになる.ただし, 詳細は文献にに委ねるとし, ここではその概要を記述するに留める.

まず流れの基礎式として式(1)に示すように, 発散 形表示させた二次元オイラー方程式を用いる.

$$
\widetilde{\nabla} \widetilde{F}=0
$$

ここで $\widetilde{\nabla} は(\partial / \partial x, \partial / \partial y, \partial / \partial t), \widetilde{F}$ は $(E, F, q)$ で あり, $E, F$ は $x$ 方向, $y$ 方向の流束べクトル, $q$ は 保存量ベクトルを示している. 次に幾何保存則を満 たすように, 式(1)を時間一空間に跨るコントロー ルボリュームについて体積積分する. 本論文ではセ ル中心法を採用するので, 検査体積は図 1 に示すよ うな五面体となる.

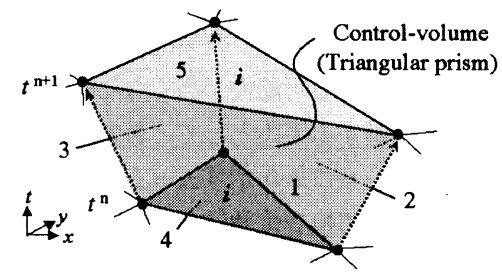

Fig.1 Control volume in space-time unified system

式(1)をこのコントロールボリュームについて体積 積分し, さらにガウスの発散定理を用いて次のよう に変形する.

$$
\begin{aligned}
& \int_{V} \widetilde{\nabla} \widetilde{F} d V=\oint_{S} \widetilde{F} \cdot \mathbf{n} d S \\
& \quad=\sum_{\ell=1}^{5}\left(E n_{x}+F n_{y}+q n_{t}\right)=0 \\
& \text { ここで } n_{\ell}=\left(n_{x}, n_{y}, n_{t}\right)_{\ell},(\ell=1,2, \cdot 5) \text { は五面体の } \ell
\end{aligned}
$$

番目の表面に対する外向き法線ベクトルである. ま た第 4 面および第 5 面は時間軸に対し垂直であるこ とから, 具体的に解くべき離散式は以下のように なる.

$$
\begin{aligned}
& q^{n+1}\left(n_{t}\right)_{5}+q^{n}\left(n_{t}\right)_{4} \\
& \quad+\sum_{\ell=1}^{3}\left\{\left(E^{n+1 / 2}, F^{n+1 / 2}, q^{n+1 / 2}\right) \cdot \mathbf{n}\right\}=0
\end{aligned}
$$

本式は時間経過と共に格子が移動する場合である. これに対し格子点を追加する場合，つまり要素を分 割する場合は次のようになる. まず検査体積を図 2 に模式的に示す.

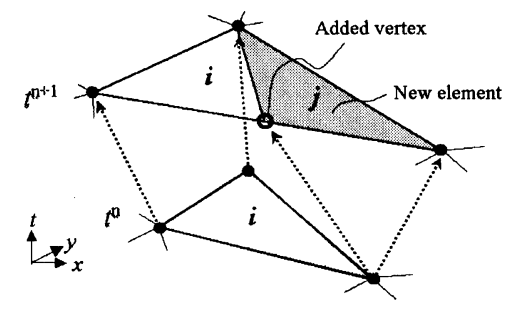

Fig.2 Control volume with addition of element

一つの要素を二つに分割する場合, 一本の格子線上 に格子点が追加されることとなり, その結果要素 $i$ は $i$ および $j$ に分割される. よって要素 $i$ は時間 $\mathrm{n}$ 段 階およびn+1 段階に挟まれた五面体（要素 $i$ ）につ いて, また要素 $i+1$ は両段階に挟まれた四面体（要 素 j）についてそれぞれ体積積分されることになる. 五面体については式(3)に示す離散式を解くことと なる. 一方四面体については, $\mathrm{n}$ 段階で面積 0 であ る要素が, n+1 段階で格子点の追加により作成され た要素を持つことになる.これは式(3)における $\left(n_{i}\right)_{4}=0$ と見なすことが出来, よって式(3)は次式の ように表すこととなる.

$$
q^{n+1}\left(n_{t}\right)_{5}+\sum_{i=1}^{3}\left\{\left(E^{n+1 / 2}, F^{n+1 / 2}, q^{n+1 / 2}\right) \cdot \mathbf{n}\right\}=0
$$

また, 格子点が消滅，つまり要素を結合する場合にはn 段階で結合すべき隣接する要素 $i$ および $j$ を合わせて取り 扱うこととなる. この場合対象となる検查体積は, 図3 に示す六面体となる. 解くべき離散式についてはn段階 で二つの要素を合わせ, 具体的に式(5)のように表すこ とになる.

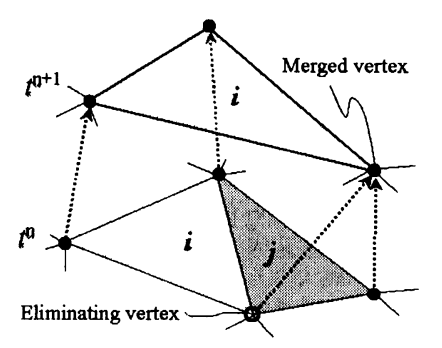

Fig.3 Control volurne with elimination of element 


$$
\begin{aligned}
& q_{i}^{n+1}\left(n_{t}\right)_{6}+q_{i}^{n}\left(n_{t}\right)_{5}+q_{j}^{n}\left(n_{t}\right)_{5} \\
& \quad+\sum_{\ell=1}^{4}\left\{\left(E^{n+1 / 2}, F^{n+1 / 2}, q^{n+1 / 2}\right) \cdot \mathbf{n}\right\}=0
\end{aligned}
$$

最終的に解くべき式(3), (4), (5)は陰的スキームで あることから擬似時間内部反復法(10)を用い, 擬似時 間の進行にはRRK法を用いた（詳細は文献(のを参照さ れたい).また, 各式における非粘性流束べクトル の評価はRoのFDS法(11)を用い, Venkatakrishnan ${ }^{(12) に よ ~}$ り提案された制限関数を使用した.

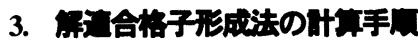

格子点の追加・消滅を伴う非構造移動格子有限体 積法を応用した解適合格子形成法について, その計 算手順を以下に記述する.

〈手㽝1〉 $n$ 時間段階の物理量を用いて解適合の 判断基準を決定する. 本論文ではセル中心法を採用 しているので, ここでは隣接する要素間の物理変化 量（物理量の一階導関数）を各要素間について計算 する. 物理変化量がユーザー指定の敷居值を越え, 分割すべき要素と判断した場合, 隣接する両方の要 素に印（印 A) を付ける. 同様に物理変化量がもう 一つの敷居値を下回り, 結合すべき要素と判断した 場合には, 両方の要素に別の印（印 B）を付ける. なお,一つの要素に印 $\mathrm{A}$ と印 $\mathrm{B}$ が同時に付いてあ る場合, 印 A を優先させる.

〈手面2〉全ての要素についてく手順 1〉を施し た後, 印 $\mathrm{A}$ の付いている要素について分割を実行 する. ここでも分割数を 2 とするため, 隣接する 2 つの要素が同時に分割されることになる. ある要素 について隣接する複数の要素に印 Aが付いていれ ば, その中で分割後の扁平率が最も小さいもの（最 も歪みが小さいもの）を選択する. ただし分割する 要素の面積が指定值（最小要素面積）を下回る場合, 分割は行わない. また, 印 $\mathrm{B}$ の付いている要素に ついて結合を行う. 分割時と同様に隣接する要素と 結合されるが，ここでも結合後の形状について扁平 率の小さいものを選択する. また結合する要素の面 積が指定値（最大要素面積）を上回る場合, 結合は 行わない.

〈手等3〉全ての分割および結合が完了すると, 歪 んだ要素に対し修正を行う. 具体的には図 4 に示す ように隣接する 2 要素間で, その境界線を入れ替え る. ただし本手順においても幾何保存則を十分に考 虑する必要が生じる. つまり, 図 5 に示すように単
に要素を回転させるだけでは幾何保存則が壊れてし まう.これは時間一空間に跨るコントロールボリュ 一ム (六面体) の側面における法線ベクトルと, 六 面体に隣接するコントロールボリュームの側面の法 線ベクトルとの間に互換性が保てなくなり，その結 果評価が正確にできなくなるからである.

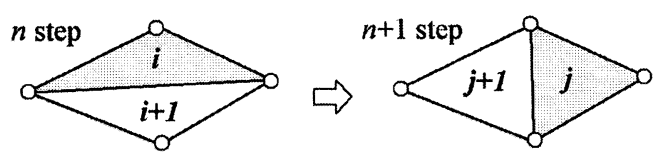

Fig.4 Replacement of a side line

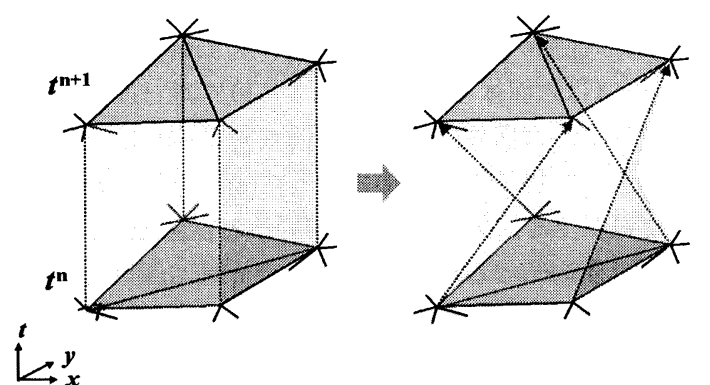

Fig.5 Mistaken method for replacement of a side line

そこで，境界線の入れ替えは次のようにして行う. まず $n$ 時間段階における境界線を入れ替える要素を $i$ および $i+1$ とする. そして図 6 に示すように $n+1$ 時 間段階において要素 $i$ は変形し要素 $i+1$ は消隇する とする. また $n+1$ 時間段階において新たに要素 $j$ が 発生する. つまり要素を $i$ および $i+1$ を形成する六 面体と, 要素 $j$ を形成する四面体を組み合わせたコ ントロールボリュームについてそれぞれ有限体積法 を適用することになる.これにより境界線を入れ替 えるコントロールボリュームについてその側面の法 線ベクトルを正しく評価することができ, 結果, 幾 何保存則を満たすことができる.

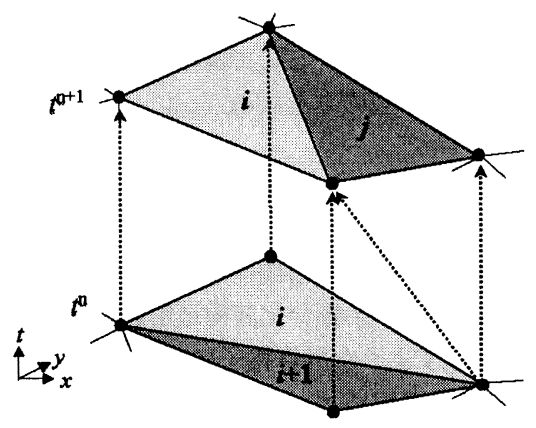

Fig.6 Control volume for replacement of a side line 
具体的に解くべき離散式については，まず. $n$ 段 階で要素を $i$ および $i+1$ を併せた六面体について次 式のように表すことになる.

$$
\begin{aligned}
q_{i}^{n+1}\left\{\left(n_{t}\right)_{8}\right\}_{i}+q_{i}^{n}\left\{\left(n_{t}\right)_{7}\right\}_{i}+q_{i+1}^{n}\left\{\left(n_{t}\right)_{7}\right\}_{j} \\
+\sum_{\ell=1}^{4}\left\{\left(E^{n+1 / 2}, F^{n+1 / 2}, q^{n+1 / 2}\right) \cdot \mathbf{n}\right\}_{\ell}=0
\end{aligned}
$$

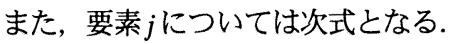

$q_{j}^{n+1}\left(n_{t}\right)_{8}+\sum_{\ell=4}^{6}\left\{\left(E^{n+1 / 2}, F^{n+1 / 2}, q^{n+1 / 2}\right) \cdot \mathbf{n}\right\}_{\ell}=0$

ここで，上式で用いた数字（1～8）は図6のコント ロールボリュームに対し，8が上底，7が下底，1〜 4 は六面体の側面，4～6は四面体の側面を示してお り，4は六面体と四面体が接する境界面である. 結 果的に，六面体は格子点が消滅する式(5)に一致し， 四面体は格子点が追加される式(4)に一致するため, プログラミングはこれらを用いると容易に行うこと ができる.

〈手順 4〉上記手順で形成された格子について，よ り滑らかな格子とするため次式に示すラプラシアン 法を用いてさらに格子の修正を行う.

$$
V(i)=\frac{1}{2 N} \sum_{\ell=1}^{N}\{V(j)+V(k)\}_{\ell}
$$

ここで $i, j, k$ は一つの三角形の 3 頂点であり, $V(i)$, $V(0), V(k)$ はそれぞれ 3 頂点の座標值を, $N$ は点 $i$ を 共有する三角形の個数を示す.これは点 $i$ を，その 点を頂点とする全ての三角形の面積の重心位置へ移 動させることを示している．ただしこの<手順 4> は毎時間段階行うと格子が鈍りすぎるため, 実際に は 10 から 15 時間段階程度毎に行うこととする.

〈手同 5>以上の手順で解適合格子が形成されるの で, この新たな格子上で内部反復計算を行い物理量 を更新する. 本来, 内部反復段階においても手順 1 から 4 を繰り返すべきであるが，収束性が悪く時間 効率が良くないので，ここでは格子の更新を各時間 段階について一回のみとする.

\section{4. スキームの证任}

まず本スキームが幾何保存則を満足しているかを 検証するため, 格子細分化非構造解適合格子を模擬 した図7に示すような計算格子に対し，一様流の捕捉 を行った. 計算領域は一辺の長さが1.0である正方形 であり，要素数は初期状態で736である．この計算格
子は，時間と共に式(9)に示す範囲内に要素の中心座 標 $\left(x_{0} y_{c}\right)$ が存在する要素に対しその要素を分割，また 範囲外に中心座標のある要素は結合させたものであ る.

$$
\begin{aligned}
& 0.1 t-0.05 \leq x_{c} \leq 0.1 t+0.05 \\
& 0.1 t-0.05 \leq y_{c} \leq 0.1 t+0.05
\end{aligned}
$$
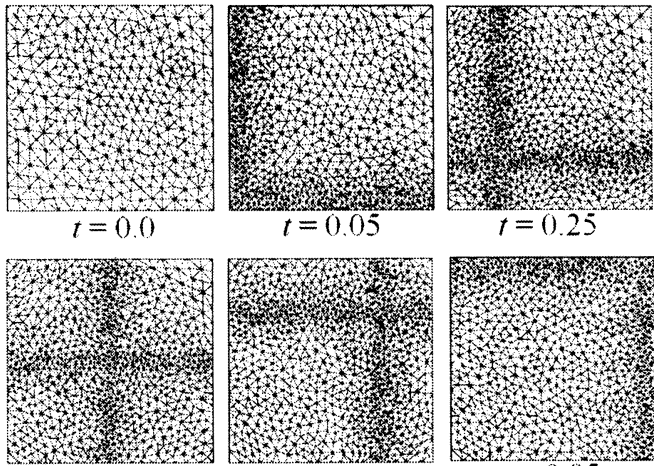

$t=0.25$

$t=0.5$
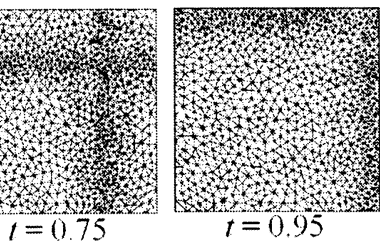

Fig.7 Change of grids for test problem

初期状態として, 全要素に一様流 $\rho_{\infty}=1.0, p_{\infty}=$ $1.0 / \gamma(\gamma=1.4), u=1.0, v=1.0$ を与え $t=10.0$ （時間刻み 幅 0.01 で 1000 時間ステップ）まで計算を行った。

図 8に密度に対する初期値との誤差履歷を示す。 また誤差は式(10)のように定義した. 結果, 初期值 との誤差は $10^{-16}$ （マシンゼロ）レベルであったこ とから, 本手法が幾何保存則を十分満足しているこ とを確認することができる.

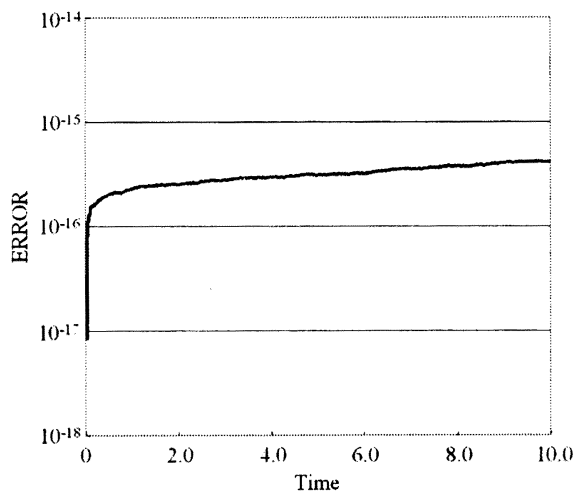

Fig.8 History of ERROR of density

$$
\text { ERROR }=\operatorname{MAX}\left[\left\{\left(\rho-\rho_{\infty}\right) / \rho_{\infty}\right\}_{i}\right]
$$




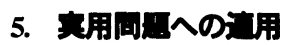

5・1 本手法の実用問題への適用 として, 図 9 に示すような衝撃波管問題を取り扱う. これはシリンダ内に高圧気体と低圧気体を隔ててい る隔膜を針で突いて破ると, 高圧気体が低圧気体側 へ一気に流れ込み，低圧気体を急激に圧縮すること で衝撃波が発生するというものである.

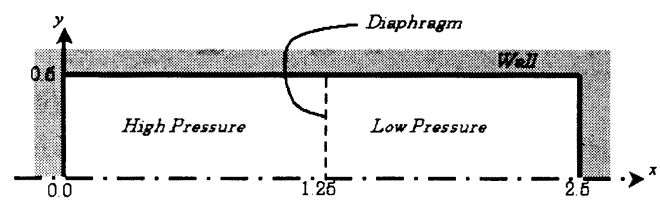

Fig.9 Shock-tube problem

初期条件として, 隔壁の左側に密度 $\rho=1.0$, 圧力 $p$ $=1.0 / \gamma(\gamma=1.4)$, 速度 $u=0.0, v=0.0$ を, 右側に $\rho=0.1$, 圧力 $p=0.1 / \gamma$ 速度 $u=0.0, v=0.0$ 与え, $t=0.0$ で隔壁 を瞬時に取り除いた後の流れ場について計算を行う. 初期格子は図 10 に示すようなデローニ一分割法を 用いて形成した. 格子数は 1000 (要素数 1862) で, $t=2.5$ (時間刻み幅 0.00125 で 2000 時間ステップ） まで計算する.

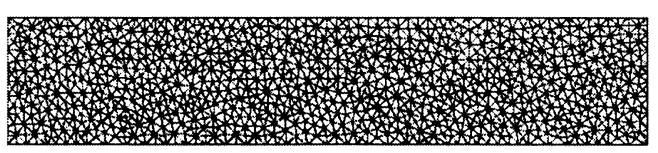

Fig.10 Initial grid

隔壁を取り除いた直後, 隔壁位置から発生した衝 撃波は右側へ，発生した膨張波は左側へそれぞれ進 行する. 右端壁へ到達した衝撃波は壁面で反射後, 強い衝撃波となり左側へ向かって進む. 本論文では 衝撃波が右端壁にて反射後の流れ場について解適合 格子形成を行った.

図 11 に計算結果を示す. 各時間段階において, 上段が形成した解適合格子を，下段が形成された解 適合格子上での流れ場（圧力分布）を示している. 部分的に不必要な格子の細分化筒所が見られるもの の, 衝撃波部には十分に格子を細分化できており, 急峻な圧力変化を捕らえられていることを確認する ことができる. また移動する衝撃波にあわせて格子 の細分化および結合を繰り返し行えている. その結 果衝撃波の移動に追従してあたかも細分箇所が移動 しているように見え, 常に衝擊波部に高密度な格子 を配置できている. なお衝撃波部の格子点数は細分
化により増加しているものの, 流れの緩やかな部分 において格子を結合させ隇少させていることから， 総格子点数はほとんど変化していない.
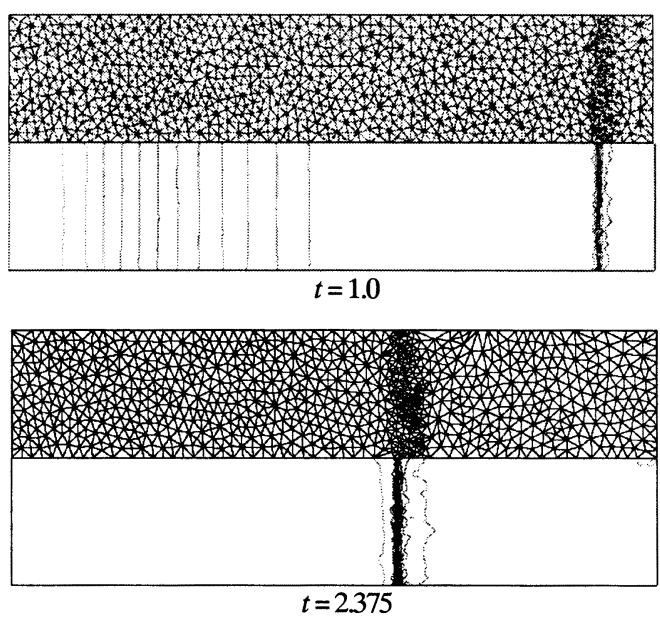

Fig.11 Grids and pressure contours for shock-tube problem

(Upper : Adaptive grid, Lower : Pressure contours)

5・2 月妵的同回次に本手法を図 12 に示す ような円柱爆縮問題に適用した.これは衝撃波管問 題の隔壁を円形に配置したものであり，隔壁の外側 部分に高圧気体が，内側部分に低圧気体がそれぞれ 充填されている. 隔壁を取り除くと同時に高圧側の 気体が低圧側へ流れ込み, 円形の衝撃波が発生する. 衝撃波は円柱の中心に向かって, また膨張波が外側 へ向かってそれぞれ進む. 衝撃波は中心に到達する と強度を増し外側へと広がっていく.

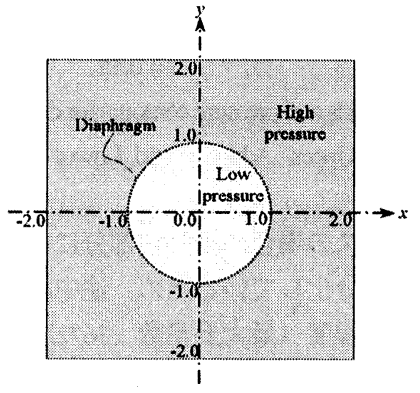

Fig.12 Cylindrical implosion problem

初期条件として, 隔壁の外側に密度 $\rho=1.0$, 圧力 $p$ $=1.0 / \gamma(\gamma=1.4)$, 速度 $u=0.0, v=0.0$ を, 内側に $\rho=0.1$, 圧力 $p=0.1 / \gamma$ 速度 $u=0.0, v=0.0$ 与え, $t=0.0$ で隔壁 を瞬時に取り除いた後の流れ場について計算を行う. 
要素数 1895 で, $t=1.25$ (時間刻み幅 0.00125 で 1000 時間ステップ）まで計算する.

図 13 に計算結果を示す. 各時間段階において, 右側が形成した解適合格子を, 左側が形成された解 適合格子上での流れ場（圧力分布）を示している. 衝撃波および膨張波（初期段階 : $t=0.55$ まで）に対 し個別に格子の細分化ができており，それぞれの波 の移動にあわせて適切な位置に格子の細分化・結合 を自動で行うことで, スムーズな格子の細分化位置 （高密度部分）の移動が実施できていることを確認 できる.
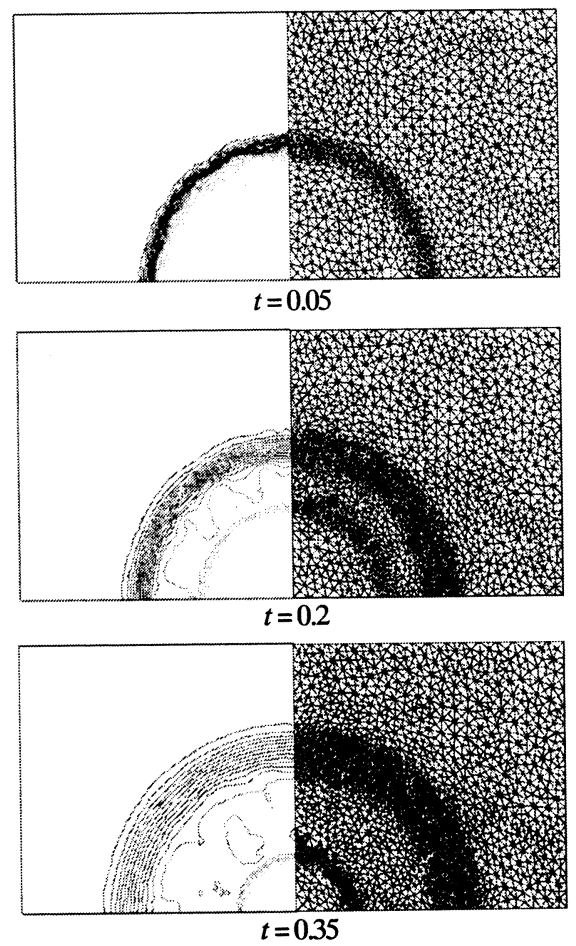

Fig.13 Grids and pressure contours for cylindrical implosion problem(Upper : Adaptive grid, Lower : Pressure contours)

本ケースの場合, 膨張波部分についてもある程度 格子を細分化しているため, 途中段階において要素 数は 2 倍程度（最大要素数 : 3672）まで増加してい るが, 衝撃波部, 膨張波部において要素面積を $1 / 10$ 程度まで小さくしている. その結果 2 倍の要素数に より 10 倍の分解能を得ていることになる. また格 子の細分箇所が複数（衝撃波および膨張波）存在し ているが, 格子の移動による解適合格子形成時に見 られた取り合いによる計算格子の部分疎化も無く, 良好な格子を形成できていることを確認することが
出来る. 尚, 本ケースにおける総計算時間は解適合 格子を行わない（格子が変化しない，つまり幾何保 存則を考慮しない) 場合と比較して約 4 倍である.

衝撃波管問題も含め 2 ケースについて本手法を適 用しそれぞれに良好な結果を得たことから，本手法 が非定常流れに対する有効な解適合格子形成法であ ることを示せた.

\section{5.}

非構造移動格子有限体積法を発展させ，解適合機 能を付加させることで，非定常流れに対する新しい 解適合格子形成法を提案した．本手法を幾つかの検 証問題へ適用した結果以下の結論を得た.

（1）非定常流れにおいて，幾何保存則を完全に 満足したまま，時間と共に格子点が追加・ 消滅する格子細分化非構造解適合格子形成 法を構築した. また検証問題を通して本手 法が完全に幾何保存則が満足されているこ とを確認した.

（2）実用問題として衝撃波管問題に適用し，衝 撃波の移動に合わせて格子点を追加・消隇 させることで，急峻な衝撃波の捕獲を確認 したことから，本手法の有効性を示した.

（3）また，円柱爆縮問題では複数の物理量急変 部に対し，的確な格子細分化を確認した. 本ケースにおいては総要素数を 2 倍程度増 加させることで約 10 倍もの計算精度を得 ることが出来た.

\section{参考文献}

(1) K. Nakahashi, AIAA J.,25-4(1987), 513-520

(2) M. J. Berge, CFD2000,(2000),337-342

(3)山川勝史他 2 名, 機論,63-609,B(1997), 1597-1603

(4)松野謙一, 数値流体力学会誌, 3-2(1995),103-114

(5)K. Matsuno 他 2 名,CFD2000,Springer,(2001),705-710

(6)山川勝史他 1 名, 機論,69-683,B(2003), 1577-1582

(7)高橋克明他 1 名, 機論,67-664,B(2001), 2946-2954

(8)R. LOHNER, International Joumal for Numerical Methods in Fluids 14(1992)1407-1419

(9)山川勝史他 1 名, 機論,70-689,B(2004), 25-30

(10)C.L.Rumsey 他 4 名,Comp.and Fluids,25,(1996),217-236

(11)Roe, P. L, JCP, 43(1981),357-372

(12) Venkatakrishnan V. (1993), AIAA Paper 93-0880 